\title{
The Influence of Website Navigational Design on Improving Tourism Performance: Empirical Studies on Sport Tourism Providers in Indonesia
}

\author{
Vanessa Gaffar $^{1}$, Oce Ridwanudin ${ }^{1}$, Bambang Trinugraha ${ }^{1} \&$ Ari Riswanto $^{2}$ \\ ${ }^{1}$ Universitas Pendidikan Indonesia, Indonesia \\ ${ }^{2}$ Sekolah Tinggi Ilmu Keguruan dan Ilmu Pendidikan PGRI Sukabumi, Indonesia \\ Correspondence: Vanessa Gaffar, Universitas Pendidikan Indonesia, Bandung, Indonesia.
}

Received: July 16, 2019

doi:10.5430/rwe.v10n3p408
Accepted: December 4, 2019

Online Published: December 15, 2019

URL: https://doi.org/10.5430/rwe.v10n3p408

\begin{abstract}
The purpose of this study is to examine and to explore the influence of website navigational design as a part of ICT, on decision to choose off road adventure service provider, as a sport tourism provider. The sample is 125 companies from varieties of type and category, by using purposive sampling. Data collected through literature review, observation and questionnaires. Path analysis is used as a data analysis technique with SPSS 20. Results shows that only search options influenced decision to choose off road adventure service provider. The other three dimensions don't have influence in decision to choose off road adventure service provider. It shows that majority of people use website only to find information and tend to see navigation bar, individual hyperlink and image maps as not important. This means that the level of website literacy among consumer is still low. It is important for companies to educate their consumers on how website could benefit them.
\end{abstract}

Keywords: website, navigational design, decision to choose, sport tourism, tourism performance

\section{Introduction}

Tourism is the driving factor of regional development. The success of tourism businesses can generate income and create new jobs. The development of tourism has influenced the tourism business itself. With the high increase in competition, every companies try to acquire, keep, and maintain their customers. They use different kinds of strategy as well as media to reach their objectives. In decades, technology is considered to be one of important factors that needs to be implemented by the company. It has played an important role in the development of tourism industry and has become indicator to determine company's success. The development of technology is used and implemented properly in tourism industry through Information, Communication, and Technology (ICT). Buhalis and Law (2008) mentioned that the tourism industry has mainly focused on using ICT for consumer and demand dimensions, technological innovations and industry functions. Through ICT, supported by internet connection, company is able to deliver service without face-to-face communication with the customers, to identify customers, to manage and distribute product more widely, and on the other hand, company can provide convenience to customers in accessing the needed information when they want to travel.

Based on survey, it is stated that internet users in Indonesia in the year of 2016 reached 132,7 million users or approximately $51,5 \%$ of the total population of 256,2 million people (Association of Indonesia Internet Provider). If we compare with that on 2014 which is 88,1 users, there is 44,6 million increased in 2 years period (http://isparmo.web.id/2016/11/21/data-statistik-pengguna-internet-indonesia-2016). Data shows that many companies use ICT through internet. Internet technology has a direct impact on companies, customers, suppliers, distributors and potential entrants into an industry (Porter, 2001). Many studies have been conducted on how this innovation will affect the nature and future of marketing activities (Shunk et al., 2007; Beheshti et al., 2006; Budiharseno, 2017). The use of ICTs has increased companies' cost-effectiveness and efficiency, for instance through revenue or yield management (Buhalis and Law, 2008), and particularly Internet has profoundly changed the ways they market, sell, and distribute their products (Werthner and Klein in Schieder, 2013; Nugroho et al., 2017). Internet has been crucial in fostering cooperation and coordination between tourism companies on a global level, in internationalizing companies' offerings, and in enabling direct communication and interaction between suppliers and consumers (Buhalis and Law, 2008). Beside, with the use of internet, consumers will be able to search for information easily related with the products offered by the company. With ICT, company could use internet to implement their 
marketing strategy. It is used by most of companies recently. Jaworsky et.al (2003) stated that marketing through internet is aimed to form market opportunity, formulate marketing strategy, design customer experience, and build relationship with customers. Many consumers have divided the process of planning and buying products into two parts i.e. search (or planning) and actual purchase. They believe that the internet is an extensively powerful medium to search, gather and explore information (Kayani, 2014). One of the internet media that often used by companies recently is website. According to Ireland (2012), websites is a marketing tool which can promote business and sell products which will be offered to target market. Taylor and England (2006) come up with four sub variables of website. Those are navigation bars, individual hyperlink, image maps, and search option.

In tourism industry, internet remains the most common way to arrange holidays. 53\% using it for this reason, $21 \%$ used someone they know, while $19 \%$ used the phone or visited a travel agency. Around $11 \%$ made the arrangements on site, while $6 \%$ used the counter at a transportation company and 3\% made arrangements by post (Flash Eurobarometer, 2013). Sport tourism, as one of the most popular tourisms which is developing recently, is also affected by ICT, especially in how they formulate the marketing strategy. One of the sports tourism which is offered in addition to hiking, rafting, and golf is off road adventure. Off-roading, according to Wikipedia is the activity of driving or riding a vehicle on unsurfaced roads or tracks, made of materials such as sand, gravel, riverbeds, mud, snow, rocks, and other natural terrain. Recently, this sports activity is becoming popular in Indonesia, especially in Bandung region. The demand of off road adventure is increasing, not only among professionals but also among amateurs. In the last 2 years, off road adventure sport tourism is increasing by $10 \%$ since 2014. Currently there are two major off road adventure service providers in Bandung, namely Bandung Off Road and Elhaqi Adventure. Although the demand is increasing, but the number of the participants hasn't reached the target set by the providers. Both providers have their own websites to inform about the company profile, the service offered, and any other information related with the product. It is indicated that the role of ICT influenced participants to choose the service providers. There are still limited study on the use of website in sport tourism industry. Therefore, it is significance to do further study on this topic. This research is aimed to explore whether the use of ICT, in this case website, influence decision to choose off road adventure service provider.

\section{Literature Review}

Tourism is activity of human movement from original place to destination place for leisure. Tourism is the sum of phenomena and relationships arising from the interaction of tourists, business, host governments, and host communities in the process of attracting and hosting these tourists and other visitors (McIntosh: 1984). Tourism is a temporarily journey, which is done from one place to another, not for business nor looking for a job but to enjoy the trip (Oka Yoeti, 1996). There are many kinds of tourism, one of which is sport tourism. Sport tourism is defined as the experience of travel to involve or to see sport-related activities. It is divided into three categories, those are sport event tourism, active sport tourism, and nostalgia sport tourism (Ross, 2001). Sport event tourism is an event focusing on sports, both professional and amateur ones such as Olympic Games or Football Tournament among High School students. Active sport tourism is when someone, or in this case tourist, actively engage on sporting events. He or she could participate in golf, hiking, running, rafting, or even joining off road adventure. Nostalgia sport tourism is when tourist visit sport related attractions such as Emirates Stadium, the home of Manchester City FC. The development of sport tourism is surpassing since nowadays sport is considered as an industry. Sports business really need to be managed properly so they can survive in the industry.

ICT in tourism industry, including sport tourism, plays a pivotal role in its development. With ICT, it allows the provider to have a direct contact with its consumer. ICT ultimately cuts costs by enabling the provider to be in direct contact with the consumer and also impact employment through the need for required maintenance of ICT equipment. Management within sport tourism business use ICT to undertake a range of tasks that enhance the efficiency of employees in the workplace, notably online reservations (Bethapudi, 2013). According to Buchalis (2003) ICT can be defined as the entire range of electronic tools that facilitates the operational and strategic management of organizations by enabling them to manage their information, functions, and processes as well as to communicate interactively with their stakeholders, enabling them to achieve their mission and objectives. Electronic tourism (e-tourism) is the application of ICT on the tourism industry. It reflects the digitization of all processes and value chains in the tourism, travel, hospitality and catering industries. The e-tourism concept includes all business functions (i.e., e-commerce, e-marketing, e-finance and e-accounting, eHRM, e-procurement, eR\&D, e-production) as well as e-strategy, e-planning and e-management for all sectors of the tourism industry, including tourism, travel, transport, leisure, hospitality, principals, intermediaries and public sector organizations. Hence, e-tourism bundles together three distinctive disciplines: business management, information systems and management, and tourism (Buhalis and Jun, 2011). 
Mobility and accessibility of the internet have brought many changes to travelers; they can make a reservation for hotels, flights, rental cars, etc. at anytime and anywhere using the mobile internet (Wang and Wang in Kwon, 2012). According to Bouras et al. (2009) and Schwartz et al. (2009) the internet has recently become a household domestic device and its uses are becoming increasingly widespread, especially after the recent development of broadband services, which has greatly facilitated easy, fast and low-cost access to the internet. The study by Evans and Smith (2004) reveals the importance of internet-based technology to improve the performance in professionals' sports clubs.

The evolution from Web 1.0 to Web 3.0 is under a long process. The first stage, Web 1.0 focused more on static web pages, a one way communication media, that enabled global information sharing but not in term of interactivity. The second stage called Web 2.0, which is focusing on people-centric. It linked people and users with user generated content capability. The third stage of web development and the most advanced one is Web 3.0. It is the Semantic Web, where meaning of content is recognized and understood by computers. It enables computer to computer interaction. (Mistilis \& Bouhalis, 2012).

Web 2.0 is the second-generation of Internet-based services, it lets people collaborate and share information online in perceived new ways-such as social networking sites, blogs, wikis, communication tools, and folksonomies (Turban et al., 2008). Website can be used to improve customer relationships by providing levels of interactivity and making the customers feel valued. (Craig Standing, Thandarayan Vasudapan, 1999). Website is a key internet marketing tool where you can promote your business and sell your products and services. Wang and Russo (2007) mentioned that the success of websites depends on the integrative application of four components as its major function: (1) up-to-date and accurate destination information provision; (2) effective and constant communication with consumers; (3) reliable and seamless electronic transaction; and, (4) appropriate and sustainable relationship building programs. Li and Wang (2010) suggested that a website should be evaluated on five dimensions, including information, communication, transaction, relationship and technical merit (ICTRT model).

Taylor and England (2006) believed that in order for consumer to be able to move quickly form one page to another page in web site, it is important for the organization to consider about web site navigational design. The four dimensions of web site navigational design used in this study consist of navigation bars, individual hyperlink, image maps, and search options. Navigation bars is the collection of structure of navigation text, images, or animations. individual hyperlink is related with connections of two web pages in a web site using navigation text, images or animations. Image maps is a number of hyperlinks in a form of images, while search options is the data entry fields enable search text to be entered to locate content in the whole website or part of website. It is believed that website has an influence on consumer's decision making process. Twumasi and Adu-Gyamfi (2013) argued that online interaction plays an important role in determining how customers' decision making process expect as well as their purchasing behavior.

According to Kotler and Keller (2016) consumer buyer behavior refers to the buying behavior of final consumers-individuals and households who buy goods and services for personal consumption. Level of consumer decision making begins with need recognition, where consumer knows his/her problems or needs. The second one is information search. This level is where consumer looks for additional information whether to increase his/her awareness or to find morea active information. The third phase is alternative evaluation where consumer use information to evaluate possibilites of alternatives brands and make a final judgement. Next step is buying decision. This is a step wehere consumer make a preference among brands in evaluation step. After consumer buy a product, the last step is post decision which is related with how the consumer feels over the product he/she bought. Since this research is only focusing on purchase decision or decision to choose off road adventure service provider, therefore there are five dimension that form purchase decision. Those are product, brand, distributor, time, quantity, and payment method. Product refers to the function and the benefit of the product itself to the consumer. Brand related with the performance of one specific brand compare with the others such as image, quality, and reputation. Distributor deals with consumer convenience to get the product. It could be based on the location, price, product availability, shopping convenience, and space. Quantity refers to how many product consumer buys in a time. It also related with the buying frequency. Finally, payment method is the availability as well as the ease of use different kinds of payment method provided.

Ritchie and Goeldner (1994) stated that to understand how traveler makes a decision for travelling, it is important to understand the decision process starting with where the idea originated, what information was gathered, who was consulted, and what led the individual to make a choice for one opportunity and reject the others. For B2B market, the decision making process consists of problem recognition, general need description, product specification, supplier 
search, proposal solicitation, supplier selection, order routine specification, and performance review (Kotler and Keller, 2016).

This study has similarities with previous research mainly about website. However, this study has differences with other research in terms of the dimension that is used. In this research, dimensions used are Navigation Bars, Individual Hyperlink, Image Maps and Search Option. Based on previous research, website has the ability in communicating a product, service, and facilities offered by the company. Thus, it could influence consumer in making a purchase decision or in tourism term is visit decision. Other differences that this study has is in theory adopted, the number of sample, the use of analysis technique and also the choice of the object itself. Based on the descriptions, the hypotheses proposed are as followings:

Hypotheses 1: Navigation bars influenced decision to choose off road adventure service provider

Hypotheses 2: Individual hyperlinks influenced decision to choose off road adventure service provider

Hypotheses 3: Image maps influenced decision to choose off road adventure service provider

Hypotheses 4: Search options influenced decision to choose off road adventure service provider

\section{Methods}

This is an exploratory research where it explores and analyzes the influence of web site navigational design, as a part of ICT, to decision to use. It also describes those two variables to get more information on what is perceived by the respondents. Data collected through literature study, observation and also by giveaway questionnaires. Questionnaires in this study is divided into three parts. Part one includes information about respondents' characteristics. Since this is a B2B study, the information consisting in this part is about the type of the company, origin, position of decision maker, and source of information other then website. Part two is about the web site navigational design which consists of 13 questions from 4 sub variables, which are Navigation Bar (X1), Individual Hyperlink (X2), Image Maps (X3), and Search Options (X4). The third part refers to Decision to Choose which consists of 12 questions from 6 dimensions. Respondents answered using a five-point Likert scale ranging from 1 (strongly disagree) to 5 (strongly agree). There are 125 corporates as our respondents. The reason why we companies were chosen as the sample of this study is because most off road adventure service provider consumers are from the company, not a direct individual consumer. Purposive sampling is used based on the criteria of the respondent knows the company website as well as already browsed and used the websites. Since the study is less then one year, so the method used is cross sectional method. Path analysis is employed using SPSS 20. The structure model is as follow.

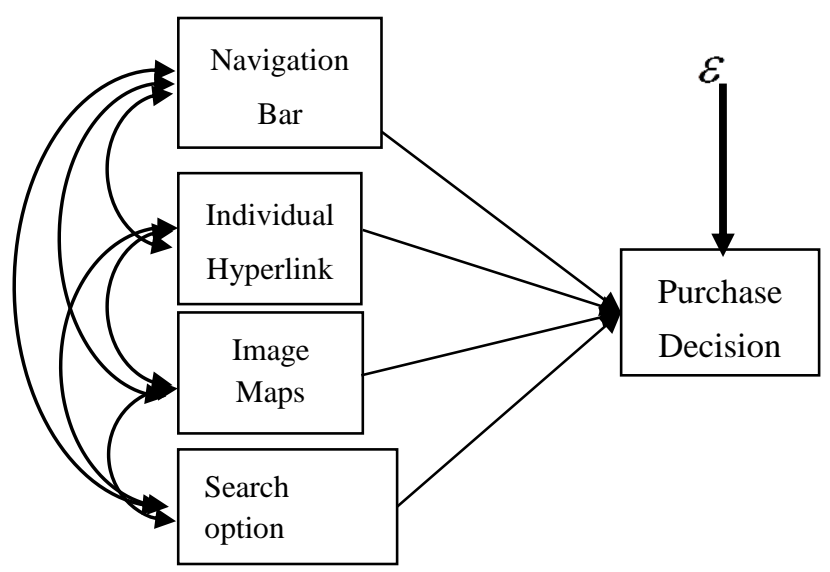

Figure 1. Hypotheses Structure Model

\section{Results and Discussion}

Descriptive statistics is used to analyze who the respondents are. It includes type of company, origin, career position, as well as source of information other then website. The first characteristic of respondent is based on the type of company. This can be categorized as Public Company, Private Company, and Education Institution. Data is shown below in Table 1. 
Table 1. Respondent characteristic based on company's type

\begin{tabular}{ll}
\hline Type & Frequency \\
\hline Public Company & 31 \\
\hline Private Company & 80 \\
\hline Education Institution & 14 \\
\hline Total & 125 \\
\hline
\end{tabular}

Table 1 shows that respondent who decided to choose service provider are dominated by private companies, which is 80 companies. This is followed by 31 public companies and 14 education institution, respectfully. It can be concluded that private companies tend to have more flexible time than both public and education institution. Moreover, they tend to have more attention to their employees since they are companies' assets.

Table 2 showed that respondents are coming from many regions. 49 companies or 36,2\% are originally from Bandung while the rest, 76 companies or 60,8\%, are from outside of Bandung, such as Jakarta, Bekasi, Bogor, or even from other islands.

Table 2. Respondent characteristic based on origin

\begin{tabular}{lll}
\hline Origin & Frequency & Percentage \\
\hline Bandung & 49 & $39.2 \%$ \\
\hline Outside Bandung & 76 & $60.8 \%$ \\
\hline Total & 125 & $100 \%$ \\
\hline
\end{tabular}

The data shown above is inline with providers' target market for those who are from outside of Bandung. Moreover, companies coming from outside of Bandung not only do the off road adventure, but also do other activities in Bandung such as shopping, culinary, etc.

Career position in a company plays an important role in decision making. In this study, the position itself is categorized by top management, head of division, and staff. The data is as follows.

Table 3. Respondent characteristic based on career position

\begin{tabular}{lll}
\hline Position & Frequency & Percentage \\
\hline Top Management & 4 & $3.2 \%$ \\
\hline Head of Division & 91 & $72.8 \%$ \\
\hline Staff & 30 & $24 \%$ \\
\hline Total & 125 & $100 \%$ \\
\hline
\end{tabular}

Table 3 shows that from the total of 125 companies, decision making is vary between one company to another, in choosing off road adventure service provider. This could be made directly by the top management, pass over to the head of division, or even to their staff. We could see that only 4 or 3,2\% decision making made by the top management. 91 companies or $72,8 \%$ give this decision to head of division, while there are only 30 companies or $24 \%$ granted the authority to their staff to decide. This means that the higher the level of management is, the more strategic the decision is. Therefore, we could see that there is only minority of companies think that choosing off road adventure service provider is considered to be the top level management's job. Moreover, it is also related with the size of the company. Since we don't differentiate the size of the company, this could be meant that the bigger the company is the more they tend to give a decision making process to the middle or even lower level management.

Information search is the early stage of consumer decsision making process. This study is divided information search other than website into three categories. Those are social media, word of mouth, and advertising. This is to know the respondent characteristic based on source of information that the respondent gets, other then website. 
Table 4. Respondent characteristic based on source of information

\begin{tabular}{llllll}
\hline & Social Media & WOM & Advertising & Total \\
\hline $\begin{array}{l}\text { Source } \\
\text { Information }\end{array}$ & of & 77 & 37 & 11 & 125 \\
\hline
\end{tabular}

Table 4 shows that 77 or $61,6 \%$ of respondents get the information of off road adventure in Bandung through social media. 37 or $25,6 \%$ from word of mouth and only 11 or $8 \%$ of respondent get the information from advertising. This means that besides website, service providers also use other promotion tools to send the message to consumers. The popularity of social media is proven to be true since majority of respondent get the information also from it. Most social media used is Facebook. However, word of mouth marketing is also considered to give information respondents need. Some of the companies get it from their relations, some from the online forum, as well as from their employees. The result shows that the lowest number is on advertising, which is only 11 or $8 \%$. This shows us that advertising, in this case, is not the best promotion tools that the service providers could use. Beside it is considered to have a higher budget that social media and WOM, the coverage is also limited to only certain area.

Descriptive analysis is also used to describe each variable based on respondents' perception. Table 6 shows the score of web site navigational design variable, which consist of navigation bar, individual hyperlink, image maps, as well as search option.

Table 5. Score of web site navigational design

\begin{tabular}{|c|c|c|c|}
\hline Sub Variables & Item & Score & Mean \\
\hline \multirow[t]{5}{*}{ Navigation Bar } & Availability of menu on website & 472 & \multirow{5}{*}{449.8} \\
\hline & Clearness of menu on website & 432 & \\
\hline & Variety of menu on website & 455 & \\
\hline & Clearness of information on website menu & 451 & \\
\hline & $\begin{array}{l}\text { The suitability of the information content to the } \\
\text { content menu on website }\end{array}$ & 439 & \\
\hline \multirow[t]{4}{*}{ Individual Hyperlink } & Variety of link on website & 460 & \multirow[t]{4}{*}{460.5} \\
\hline & $\begin{array}{l}\text { Clearness of link in the form of text or image on } \\
\text { website }\end{array}$ & 469 & \\
\hline & Availability of link to social media & 462 & \\
\hline & Ease of finding symbols or icon link & 451 & \\
\hline \multirow[t]{2}{*}{ Image Maps } & Availability of menu in the form of image & 454 & \multirow[t]{2}{*}{445.5} \\
\hline & Ease of finding image content & 437 & \\
\hline \multirow[t]{2}{*}{ Search Option } & Availability of search engine & 460 & \multirow[t]{2}{*}{454.5} \\
\hline & Reliability of searching result & 449 & \\
\hline
\end{tabular}

From the Table 5, it can be seen that the highest mean among those sub variables is individual hyperlink. It is related with the variety of link, clearness of link in the form of text or image, availability of link to social media, and ease of finding symbols or icon link. This shows that respondents are fully aware of individual hyperlink and perceived it as a good think for website to offer. They tend to know what it is but they tend no to use it as a benefit tools in decision making. While the highest mean is individual hyperlink, the lowest one is image maps. It consists of availability of menu in the form of image and the ease of finding image content. The data reveals that image is not important as perceived by the respondents. A long as the menu give a clear information, it does not really matter whether the form of the menu itself is in image or text. Table 6 consists of score for decision to choose variable. It is divided into six parts, which are product selection, brand selection, distributor selection, time, quantity, and payment method. 
Table 6. Score of decision to choose

\begin{tabular}{|c|c|c|c|}
\hline Variables & Item & Score & Mean \\
\hline \multirow[t]{12}{*}{ Decision to choose } & Off-road adventure product advantages offered & 487 & 484 \\
\hline & Variety of off-road adventure package offered & 481 & \\
\hline & $\begin{array}{l}\text { Popularity of off-road adventure in Bandung } \\
\text { region }\end{array}$ & 484 & 484 \\
\hline & $\begin{array}{l}\text { Accessibility of location off-road adventure } \\
\text { provider }\end{array}$ & 462 & 472 \\
\hline & Ease of accessing provider's website & 482 & \\
\hline & Off-road adventure based on needs & 463 & 473 \\
\hline & Off-road adventure on holiday & 466 & \\
\hline & Off-road adventure on weekend & 490 & \\
\hline & Numbers of participants in each trip & 475 & 471,5 \\
\hline & Frequency of off-road adventure in one year & 468 & \\
\hline & Variety of payment method & 466 & 463 \\
\hline & Ease of payment & 460 & \\
\hline
\end{tabular}

Data shows that both selection of product as well as selection of brand have the highest mean. Product advantages, package offered, and the popularity of the service provider are considered to be important compare with other items. As we know that off-read adventure is becoming popular recently, that is why people would like to know how it feels. They want to have different experience compare with other tourism activities, even compare with other sport tourism. The lowest mean is in the payment method. Respondents do not consider this item as good since there are not many variety of payment method that is offered. Although each provider has its own website, but when it comes to payment, they do not provide online transaction.

In this study, it also examines the correlations between independent variable, web site navigational design, which consists of navigation bar, individual hyperlink, image maps, and search option and dependent variable, that is decision to choose. This can be shown in Table 8 .

Table 7. Correlation between web site navigational design and decision to choose

\begin{tabular}{lllll}
\hline \multicolumn{2}{l}{ Model Summary } & & \\
\hline Model & $\mathrm{R}$ & R Square & Adjusted R Square & Std. Error of the Estimate \\
\hline 1 & $.347 \mathrm{a}$ & .120 & .091 & 5.458 \\
2 & $.341 \mathrm{~b}$ & .116 & .094 & 5.448 \\
3 & $.328 \mathrm{c}$ & .108 & .093 & 5.452 \\
\hline
\end{tabular}

a. Predictors: (Constant), $\mathrm{x} 4, \mathrm{x} 2, \mathrm{x} 1, \mathrm{x} 3$

b. Predictors: (Constant), $\mathrm{x} 4, \mathrm{x} 1, \mathrm{x} 3$

c. Predictors: (Constant), $\mathrm{x} 4, \mathrm{x} 1$

Data in Table 7 shows that there are three testing models in this study. The first model shows correlations score (R) of web site navigational design on decision to choose, which is 0.347 . This means that the correlations of both variables lies on weak category since the score is under 0.5 . The second model shows correlations score (R) of 0.34 . It also means that the correlation is weak, as well as the last model, with the correlations score (R) of 0.328 which also means in a weak correlation.

Table 7 also explains the influence of each web site navigational design sub variables to decision to choose, simultaneously, with the score of 0.120 or $12 \%$. It also influenced by other variables which are not included in this study, by $82 \%$. For the second and third model, each has influenced of 0.116 or $11.6 \%$ and 0.108 or $10.8 \%$, respectively. This model is influenced by other variables which are not included in this study by $88.4 \%$ and $89.2 \%$. 
ANOVA or F-Testing is examine to know whether the proposed model fit with the data. It also finds the simplest model of this study. This testing is done by comparing F score with $\mathrm{F}$ table or by looking at the level of significance with the rule of the significance score needs to be higher than 0.05 . Table 8 shows the result of ANOVA output.

Table 8. ANOVA testing

\begin{tabular}{lllllll}
\hline Model & & Sum of Squares & Df & Mean Square & F & Sig. \\
\hline 1 & Regression & 488.937 & 4 & 122.234 & 4.104 & $.004 \mathrm{~b}$ \\
& Residual & 3574.215 & 120 & 29.785 & & \\
& Total & 4063.152 & 124 & & & \\
2 & Regression & 471.465 & 3 & 157.155 & 5.294 & $.002 \mathrm{c}$ \\
& Residual & 3591.687 & 121 & 29.683 & & \\
& Total & 4063.152 & 124 & & & $.001 \mathrm{~d}$ \\
& Regression & 437.164 & 2 & 218.582 & 7.354 & \\
& Residual & 3625.988 & 122 & 29.721 & & \\
& Total & 4063.152 & 124 & & & \\
\hline
\end{tabular}

a. Dependent Variable: $y$

b. Predictors: (Constant), $\mathrm{x} 4, \mathrm{x} 2, \mathrm{x} 1, \mathrm{x} 3$

c. Predictors: (Constant), $\mathrm{x} 4, \mathrm{x} 1, \mathrm{x} 3$

d. Predictors: (Constant), $\mathrm{x} 4, \mathrm{x} 1$

Table 8 shows that there are 3 models in this study. Form all 3 models, model 3 is the fittest one, with the F score of 218.582 and the significance level of 0.001 . Therefore, the testing could be continued to the next step, which is coefficient testing for each sub variables.

Table 9. Coefficients

\begin{tabular}{|c|c|c|c|c|c|c|}
\hline \multirow{2}{*}{\multicolumn{2}{|c|}{ Model }} & \multicolumn{2}{|c|}{ Unstandardized Coefficients } & \multicolumn{3}{|c|}{ Standardized Coefficients } \\
\hline & & B & Std. Error & Beta & $\mathrm{t}$ & Sig. \\
\hline \multirow[t]{5}{*}{1} & (Constant) & 27.769 & 5.098 & & 5.446 & .000 \\
\hline & $\mathrm{x} 1$ & .287 & .197 & .129 & 1.454 & .149 \\
\hline & $\mathrm{x} 2$ & .176 & .230 & .069 & .766 & .445 \\
\hline & $\mathrm{x} 3$ & .414 & .470 & .079 & .881 & .380 \\
\hline & $\mathrm{x} 4$ & .961 & .315 & .266 & 3.053 & .003 \\
\hline \multirow[t]{4}{*}{2} & (Constant) & 29.209 & 4.731 & & 6.174 & .000 \\
\hline & $\mathrm{x} 1$ & .322 & .192 & .144 & 1.677 & .096 \\
\hline & $\mathrm{x} 3$ & .493 & .458 & .094 & 1.075 & .285 \\
\hline & $\mathrm{x} 4$ & .957 & .314 & .265 & 3.045 & .003 \\
\hline \multirow[t]{3}{*}{3} & (Constant) & 31.868 & 4.035 & & 7.897 & .000 \\
\hline & $\mathrm{x} 1$ & .345 & .191 & .155 & 1.810 & .073 \\
\hline & $\mathrm{x} 4$ & 1.017 & .310 & .281 & 3.282 & .001 \\
\hline \multicolumn{7}{|c|}{ a. Dependent Variable: y } \\
\hline
\end{tabular}

Partial testing, as it is shown in Table 10, explains that in the first model, Navigation Bar sub variable (X1) has a path coefficient score of 0,129 with the significance level of 0,149. For Individual Hyperlink (X2), it has a path coefficient score of 0.069 and the significance level of 0,445. For Image Maps (X3) and Search Options (X4) sub variables, each of path coefficients sore is 0.079 and 0.266 respectively. The significance level for those two sub variables are 0.380 and 0.003 . This can be seen in path diagram structure below. 


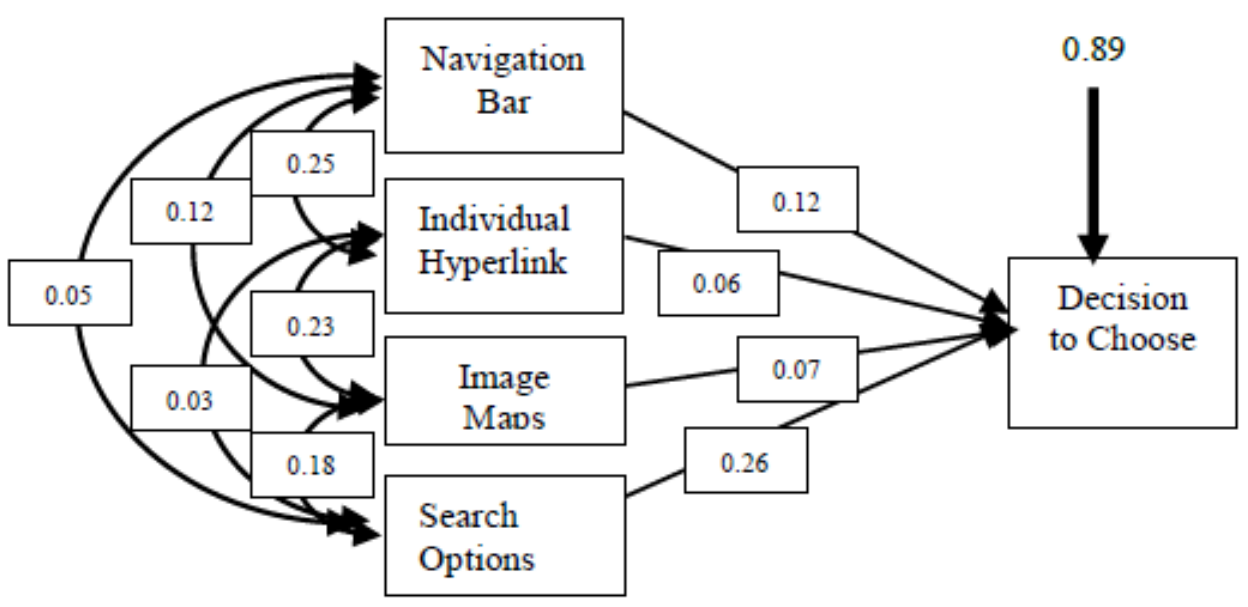

Figure 2. Path diagram

Figure 2 above shows path diagram of hypotheses testing. Based on the path coefficient testing, there are three path coefficients which are not significant since they have level of significance above 0.005 . Those are Navigation bar, Individual Hyperlink, and Image Maps sub variables. Therefore, to have the fittest model, trimming process needs to undertake. We have to exclude the insignificance sub variables from the path diagram. From the data analysis in Table 8 , it can be shown below.

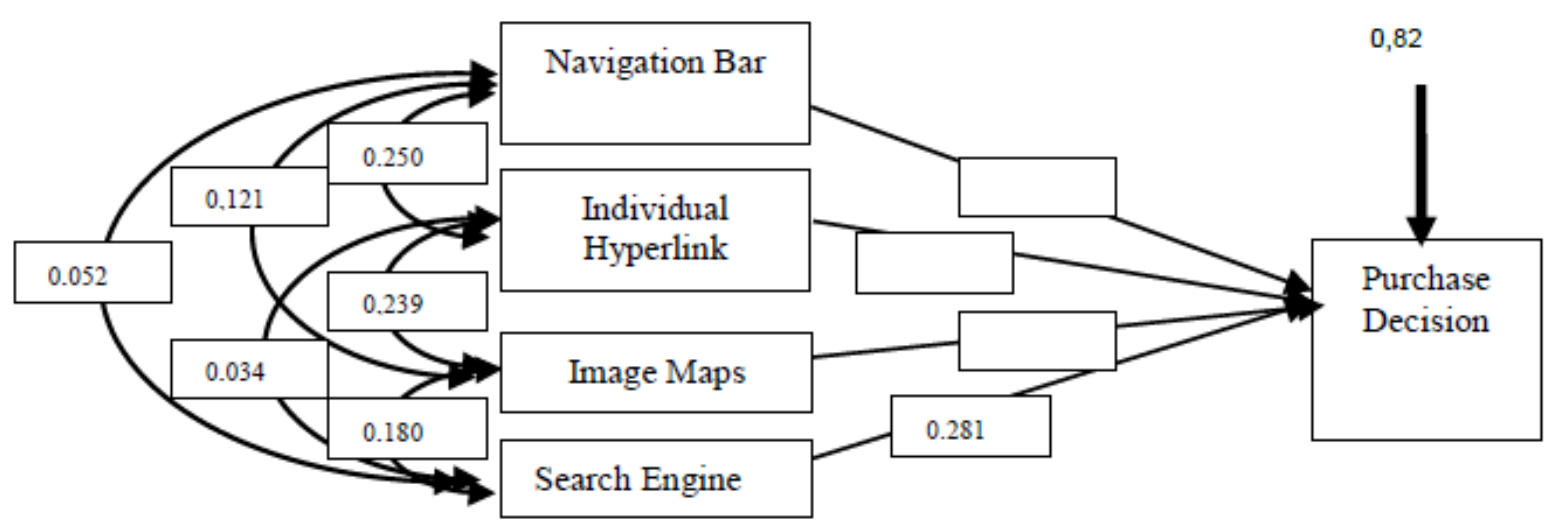

Figure 3. Path diagram after trimming process

Figure 3 shows that after excluding insignificance sub variables, which are Navigation Bar (X1), Individual Hyperlink (X2), and Image Maps (X3), it could be seen that the coefficient score for Search Options (X4) sub variable is 0.281 with the level of significance of 0.001 . This means that from all four sub variables of Website, only Search Options (X4) sub variables which has an influence on decision to choose off road adventure service provider.

\section{Conclusion}

This study investigates web sites navigational design and decision to choose off-road adventure service provider. It shows that the variety of company's type, the origin, the career position of decision maker, and the source of information beside web site does not affect decision to choose off-road adventure service provider. Characteristic of respondents highlights that differences occurred among them. Descriptive analysis shows that among four sub variables of web site navigational design, individual hyperlinks perceived by respondents as the best one compare with the others. What is interesting here is respondents know it is a good thing but they do not use it to help the decision 
making process. Respondents perceived image maps as the worse among other since most of the menu is in the text form. For decision to choose variable, it can be concluded that selection of product and brand are the best among other items. The popularity of off-road adventure becoming one factor that contributes. Payment method needs to be fixed, in terms of the variety as well as the easiness.

This study reveals that the only sub variable of web site navigation design which influence decision to choose, is search options. It can be concluded that search options is considered to be the most useful "tools" in web site navigational design. Majority of respondents use web site to find information on service provided. Therefore, they will concentrate on how to get the information, mostly by using the search options.

This study provides the significance of how sports tourism can be improved by the use of website design that provides useful navigation for this tour. Traditionally, this kind of tourism has been explored with little regard for the need for internet-based navigational designs for tourists. This study examines how navigational web design is useful in enhancing the sports experience for users. In addition, this study significantly demonstrates that internet use can be useful for the exploration of experience-based tours, and overall tourism improvement. It is important for the off-road adventure service providers to rethink of navigational design of their web sites. It is also important to evaluate web site regularly to maximize the use of it. Service providers have to think for further improvement that web site is not only to provide information about the product, but it could also be as a mean to do the transaction electronically. Educating potential consumers on web literacy will also help providers to develop a more interesting and user friendly website.

This study has some limitations. It only covers website as one of technological product as well as a promotional tool that influence decision to choose off road adventure service provider. Further study needs to include other promotional tools or make a comparison between online and offline promotional tools that influence decision to choose. This study is a B2B study where the sample is business market, in this case companies. Further study could focus on B2C, where the sample is individual consumer. It might bring a different result.

\section{References}

Bethapudi, A. (2013). The role of ICT in tourism industry. Journal of Applied Economics and Business, 1(4), 67-79.

Budiharseno, R. S. (2017). Factors affecting online buying behavior on g-market site among international students in Busan: A qualitative research. Arthatama: Journal of Business Management and Accounting, 1(1), 1-5.

Buhalis, D. (2003). eTourism: Information technology for strategic tourism management. Pearson Education.

Buhalis, D., \& Jun, S. H. (2011). E-tourism. Contemporary Tourism Reviews, 1, 2-38.

Buhalis, D., \& Law, R. (2008). Progress in information technology and tourism management: 20 years on and 10 years after the Internet-The state of eTourism research. Tourism Management, 29(4), 609-623.

Dedeke, A. N. (2016). Travel web-site design: Information task-fit, service quality and purchase intention. Tourism Management, 54, 541-554.

Duong, L. (2012). Practice of Internet Marketing in Destination Branding. Theses, Savonia University of Applied Science.

Evans, D. M., \& CT Smith, A. (2004). Internet sports marketing and competitive advantage for professional sports clubs: bridging the gap between theory and practice. International Journal of Sports Marketing and Sponsorship, 6(2), 9-21.

Flash Eurobarometer. (2013). Attitudes of Europeans towards tourism. European Commision.

Horrigan, J. B. (2008). The internet and consumer choice: Online Americans use different search and purchase strategies for different goods. Pew Internet and American life project.

Jaworsky, B., Gordon, P., Fisher, J. R., \& Rafi, M. (2003). Internet Marketing Building Advantage in a Networked Economy. Boston: McGraw Hill

Kayani, K. (2014). Impact of internet communication technology on bricks \& mortar travel agents and changes in supply chain positioning. Information and Communication Technologies in Tourism, 40.

Kotler, P., \& Keller, K. L. (2016). Marketing management. New Jersey: Pearson Prentice Hall.

Li, X., \& Wang, Y. (2010). Evaluating the effectiveness of destination marketing organisations' websites: Evidence from China. International Journal of Tourism Research, 12(5), 536-549.

Loiacono, E. T., Watson, R. T., \& Goodhue, D. L. (2007). WebQual: An instrument for consumer evaluation of web sites. International Journal of Electronic Commerce, 11(3), 51-87. 
Malik, M. E., Ghafoor, M. M., Hafiz, K. I., Riaz, U., Hassan, N. U., Mustafa, M., \& Shahbaz, S. (2013). Importance of brand awareness and brand loyalty in assessing purchase intentions of consumer. International Journal of Business and Social Science, 4(5).

Mistilis, N., \& Buhalis, D. (2012). Challenges and potential of the Semantic Web for tourism. e-Review of Tourism Research (eRTR), 10(2).

Mo Kwon, J., Bae, J. I., \& Blum, S. C. (2013). Mobile applications in the hospitality industry. Journal of Hospitality and Tourism Technology, 4(1), 81-92.

Noti, E. (2013). Web 2.0 and the its influence in the tourism sector. European Scientific Journal, 9(20).

Nugroho, A. H., Bakar, A., \& Ali, A. (2017). Analysis of technology acceptance model: Case study of Traveloka. Arthatama: Journal of Business Management and Accounting, 1(1), 32-37.

Oka A. Y. (1996). Pemasaran Pariwisata. Bandung: Angkasa.

Oklobdzija, S. (2014). The importance of internet marketing communication in event tourism. Case study: Exit festival.

Overview of Internet $\quad$ Marketing. (2012, April $\quad 2)$ Retrieved from http://www.failteireland.ie/FailteIreland/media/WebsiteStructure/Documents/2_Develop_Your_Business/3_Mar keting_Toolkit/3_Market_Your_Business_Online/Choose\%20Your\%20Internet\%20Tools/HowToGuide_IntMr ktingOverview_v1-0.pdf

Park, H. W. (2003). Hyperlink network analysis: A new method for the study of social structure on the web. Connections, 25(1), 49-61.

Porter, M. (2001). Strategy and the internet. Harvard Business Review, 75(3).

Ritchie, B.J.R., \& Goeldner, C. R. (1994). Travel, tourism, and hospitality research: a hand book for managers and researchers (2th ed.). John Wiley and Sons.

Robert W. M. (1984). Tourism Principles, practices. John Wiley \& Sons.

Schieder, T. K. (2013). Mobile applications for unesco world heritage sites. Università Della Svizzera Italiana, Lugano Switzerland.

Shiau, W. L., \& Yeh, K. H. (2012). The Effects Of Information Richness And Navigation On Value And Behavior Intentions: The Case Of Groupon Taiwan. In PACIS (p. 130).

Shunk, D. L., Carter, J. R., Hovis, J., \& Talwar, A. (2007). Electronics industry drivers of intermediation and disintermediation. International Journal of Physical Distribution \& Logistics Management, 37(3), 248-261.

Standing, C., \& Vasudavan, T. (1999). Internet marketing strategies used by travel agencies in Australia. Journal of Vacation Marketing, 6(1), 21-32.

Taylor, M. J., \& England, D. (2006). Internet marketing: web site navigational design issues. Marketing Intelligence \& Planning, 24(1), 77-85.

Turban, E., King, D., McKay, J., Marshall, P., Lee, J., \& Viehland, D. (2008). Electronic Commerce 2008: A Managerial Perspective. Upper Saddle River, NJ: Pearson Education, Inc.

Twumasi, A., \& Adu-Gyamfi, K. (2013). The Impact of Social Networking Sites on the Purchasing Behaviours of Online Travel Community Members. Information and Knowledge Management, 3(11), 105-111.

Wang, Y., \& Russo, S. M. (2007). Conceptualizing and evaluating the functions of destination marketing systems. Journal of Vacation Marketing, 13(3), 187-203. 